\title{
A Large Evaluation of Passerine Cisticolids (Aves: Passeriformes): More About Their Phylogeny and Diversification
}

\author{
Billy Nguembock*,1, Corinne Cruaud ${ }^{2}$ and Christiane Denys ${ }^{3,4}$
}

${ }^{1}$ Laboratoire de Zoologie, Département de Biologie et Physiologie Animales, Université de Yaoundé I, BP 812 Yaoundé, Cameroun

${ }^{2}$ Génoscope, Centre National de Séquençage, 2, rue Gaston Crémieux, CP5706, 91057 Evry Cedex, France

${ }^{3}$ UMR 7205 Unité Origine, Structure et Evolution de la Biodiversité, Département Systématique et Evolution, Muséum National d'Histoire Naturelle, 55 Rue Buffon, 75005 Paris, France

${ }^{4}$ Service de Systématique Moléculaire, IFR CNRS 101, Muséum National d'Histoire Naturelle, 43, Rue Cuvier, 75005 Paris, France

\begin{abstract}
African warblers (or Cisticolidae family) are small perching song birds with a large number of genera distributed throughout the World. The phylogeny of Cisticolidae is well-supported but their diversification is currently poorly known. To deepen their understanding of phylogeny and investigate their diversification, we sequenced four loci (mitochondrial ATPase 6, ND2 and ND3, and nuclear myoglobin intron 2) for several new cisticolid taxa and added several other sequences. Our analyses retrieve the monophyly of the African warblers and confirm Neomixis as their deepest branch. A group of taxa appear as their potential sister-taxa with our ND2 analyses but not with our combined analyses. New relationships are well-supported. Thus Scotocerca inquieta nests in the cettid clade whereas Camaroptera superciliaris, Cisticola chubbi, Cisticola tinniens, Prinia flavicans and Poliolais lopezi belong to the cisticolid clade. Our results support a splitting of the African warblers in two main clades. The first clade consists of genera Orthotomus, Prinia, Cisticola, Scepomycter, Incana, Bathmocercus, Eminia, Hypergerus and Heliolais while the second includes genera Poliolais, Camaroptera, Urolais, Artisornis, Oreolais, Apalis, Schistolais, Calamonastes and Spiloptila. Our results confirm the polyphyly of Orthotomus which generates a muddle between some Cettia species and other Asian tailorbirds. Waiting a study with Orthotomus sepium Horsf., 1821, to clarify their taxonomy, we suggest temporarily that the name Phyllergates cucullatus Temminck, 1836, refers to Orthotomus cucullatus of the present study. Our dating analysis reveals that cisticolid clades began their diversification during the transition Early-Middle Miocene epoch and at the beginning of the Pliocene epoch. The diversification of the "open cisticolid" clade would have occurred during the Middle Miocene but that of the "forest cisticolid" lineage would have taken place during the Upper Miocene.
\end{abstract}

Keywords: African warblers, maximum-likelihood, Bayesian inference, polyphyly, taxonomy, molecular dating, diversify cation, Miocene, Pliocene.

\section{INTRODUCTION}

African warblers represent an Old World passerine clade of tropical birds which has been established [1]. Several cisticolid genera are endemic to Africa or of obvious African origin. These warblers are small (around $9 \mathrm{~cm}$ ) but some are medium size $(19-20 \mathrm{~cm})$. Cisticolid taxa often have underparts and head more distinctively patterned than their upperparts. On average, males are larger than females and the length of their tail is often more dimorphic [2]. The cisticolid bill is rather short, slender or long. Their wings are short and rounded but the number of tail feathers varies among the genera. Some cisticolid genera like Orthotomus, Heliolais, Cisticola, Incana, Camaroptera, Calamonastes, Euryptila and Spiloptila have twelve rectrices and others only ten or eight [2-4]. The cisticolid plumage colour varies from drab and cryptic to brightly coloured.

*Address correspondence to this author at the Department of Animals Biology and Physiology, Faculty of Sciences, University of Yaounde I, P.O. Box 812 Yaounde, Cameroon; Tel: 00237 94144294;

Fax: 00237222353 86; E-mail: billyngue@yahoo.fr
For many years, the cisticolid clade was included in the Old World Warblers (Sylviidae) but after the work of Sibley and Ahlquist [1], it has been erected to the family level. Afterwards, several molecular studies have strongly confirmed this clade [5-8]. Interestingly, considerable taxonomic advances have been achieved in keeping with the cisticolid clade. Several studies showed that Rhopophilus pekinensis did not belong to cisticolid clade but genera Bathmocercus and Orthotomus belonged to it $[8,3]$. Concerning tailorbirds, Nguembock et al. [3] showed that African tailorbirds (Artisornis) were distantly related to Asian tailorbirds (Orthotomus). Otherwise, Nguembock et al. [3] found that the Moreau Warbler, which was always included in the genus Bathmocercus, was rather distantly related to it; they used this result to resurrect the genus Scepomycter [3].

In another study, Nguembock et al. [4] proposed a new generic name, Oreolais, for odd putative apalises pulchra and ruwenzorii. Johansson et al. [9] found that the ancient sylviid genus Eremomela nested within the cisticolid clade. Equally, Nguembock et al. [10] also found that Scotocerca 
inquieta nested within the cettid clade. Other subjects have been developed concerning this clade, for instance, the adaptation of the main basic nest type to their environment, the evolution of the stitching technique in "tailorbirds" but in return these studies did not shyly tackle subjects in keeping with their sister group, origin or diversification $[3,6]$.

According to diverse authors [3, 4, 8-11], the cisticolid clade constitutes a well diversified family which includes approximately 29 genera. These genera are distributed throughout the World and their origin is currently unknown. Our first results [3] suggested that some genera should have colonized the African mainland but we do not know how or when. In this study [3], we found that the insular genus Neomixis was their basal branch. Their closest relatives are currently poorly known. Beresford et al. [7] found that the cisticolid clade was close to some Pycnonotidae or Timaliidae taxa but this relationship was unresolved. Often regarded to be close to sylviid taxa, Alström et al. [8] failed to confirm this relationship while Nguembock et al. [3] obtained just a moderate support for the Yellow Longbill like their sister-taxon but only with the ND2 gene.

Aims of this study which includes several new cisticolid taxa were to enlarge a thorough knowledge of this group, to investigate their relationships and to obtain support for their sister-taxa. Otherwise leaning on our molecular dating, we aimed to discuss preliminary elements of their origin and diversification. We used $2716 \mathrm{bp}$ of aligned sequenced data obtained from three mitochondrial protein-coding genes (ATPase 6, ND2 and ND3) and one intron (myoglobin intron 2).

\section{MATERIALS AND METHODS}

\section{Taxon Sampling}

Samples used comprised tissues from fresh specimens as well as Genbank and Embl-bank sequences. Fresh tissues came from banks of tissues (ZMUC, MNHN and FMNH) and others directly collected in Cameroonian highlands forests. We included 20 some 28 potential genera listed under Cisticolidae [12] and updated by recent molecular works [3, $4,8,9]$. We added several taxa which are closely related to the cisticolid clade $[3,4,7,8]$ and other insular genera which could be closest relatives of this clade [5, 13]. To discuss the origin and the diversification of the cisticolid taxa within the Passerida, we additionally sampled 11 oscine passerine families recognized in Dickinson [12] and two recent suggested families (Stenostiridae and Picathartidae) [7, 14, 15] (Annexe). We selected one Monarchid, Tersiphone rufiventer, as an outgroup which was demonstrated outside the cisticolid clade [16]. Our molecular dataset was also increased by including ND2 and myoglobin intron 2 sequences taken in Genbank and Embl-bank (Annexe). A total of 123 Operational Taxonomic Units are included in our analyses (Annexe).

\section{Laboratory Procedure}

Genomic DNA was isolated from fresh tissues (blood or muscle) using a CTAB-based protocol [17]. We amplified and sequenced four gene regions which are known to have different evolutionary rates in birds, one evolving slowly (myoglobin intron 2) and others more rapidly (ATPase 6, ND2 and ND3). The mitochondrial ATPase 6 (684 bp) and ND3 (351 bp) were amplified as a single fragment $[18,19]$ whereas ND2 (1041 bp) as a single fragment [20] or as several smaller fragments. The nuclear myoglobin intron $2(\sim$ $624 \mathrm{bp)}$ was amplified as a single fragment and conditions described by Heslewood et al. [21] and Slade et al. [22] or as several smaller fragments. All these primers are detailed in Table 1.

For amplifications, cycling conditions were standard for these four markers $[3,4,10]$. Three microliters of the PCRamplification product was electrophoresed on a $1.5 \%$ agarose gel and visualized under UV light with ethidium bromide to check the size of the fragment and hence ensure that the correct fragment had been amplified. We purified the PCR-amplification product using the 'QiaQuick PCR Purification Kit' (Qiagen, Holden, Germany). The purified products were cycle-sequenced using a 'Big Dye' (Applied Biosystems Inc, Forster City, CA, USA). Sequences were obtained on an ABI3100 sequencer. All sequences of ND2, ND3 and ATPase 6 were aligned using the algorithm in Sequencher 3.1. No insertions, deletions and stop-codons were detected in the reading frame of these three proteincoding genes suggesting that our sequences are of mitochondrial origin and not nuclear pseudogenes [23]. For the nuclear intron, sequences were aligned using Sequencher 3.1 and then exported to BioEdit v6.0.5 [24] where they were aligned more precisely by eye; these alignments indicated the presence of several insertion/deletion events. The occurrence of Single Nucleotide Polymorphisms (SNPs) in this locus was suggested by the presence of double peaks; theses double peaks were coded using the appropriate IUPAC codes.

\section{Phylogenetic Analyses}

Two methods were used to infer phylogenetic relationships. Maximum Likelihood (ML) and Bayesian Inference (BI) analyses were conducted for each dataset separately (ND2-96 taxa; ATPase 6-79 taxa; ND3-80 taxa; myoglobin intron 2-103 taxa) and for the combined dataset (67 taxa). Gaps were treated as missing data. The topologies and parameters estimated were obtained for the $\mathrm{ML}$ and $\mathrm{BI}$ with PhyML v2.4 [25] and MrBayes v.3.1 [26], respectively. The model of sequence evolution was selected using the Akaike Information Criterion as implemented in the MrMODELTEST 2.0, running in conjunction with PAUP* 4.0b [27-29]. The selected models were then used for the separate ML analyses; these models and parameters estimated (base frequencies, rate matrix, shape parameter, proportion of invariable sites) are detailed in legends of the figures (Figs. 1-4). Nodal supports in ML were estimated with 1000 bootstrap pseudo-replicates [30].

Bayesian inference was conducted for each dataset, and models as determined by MrMODELTEST 2.0 were applied to estimate optimal parameters. Four incrementally heated Metropolis-coupled Monte Carlo Markov chains were run for three million generations with trees sampled every 100 generations (30 001 trees sampled). With our sample, the stationarity was rapidly reached; the first 300000 genera- 


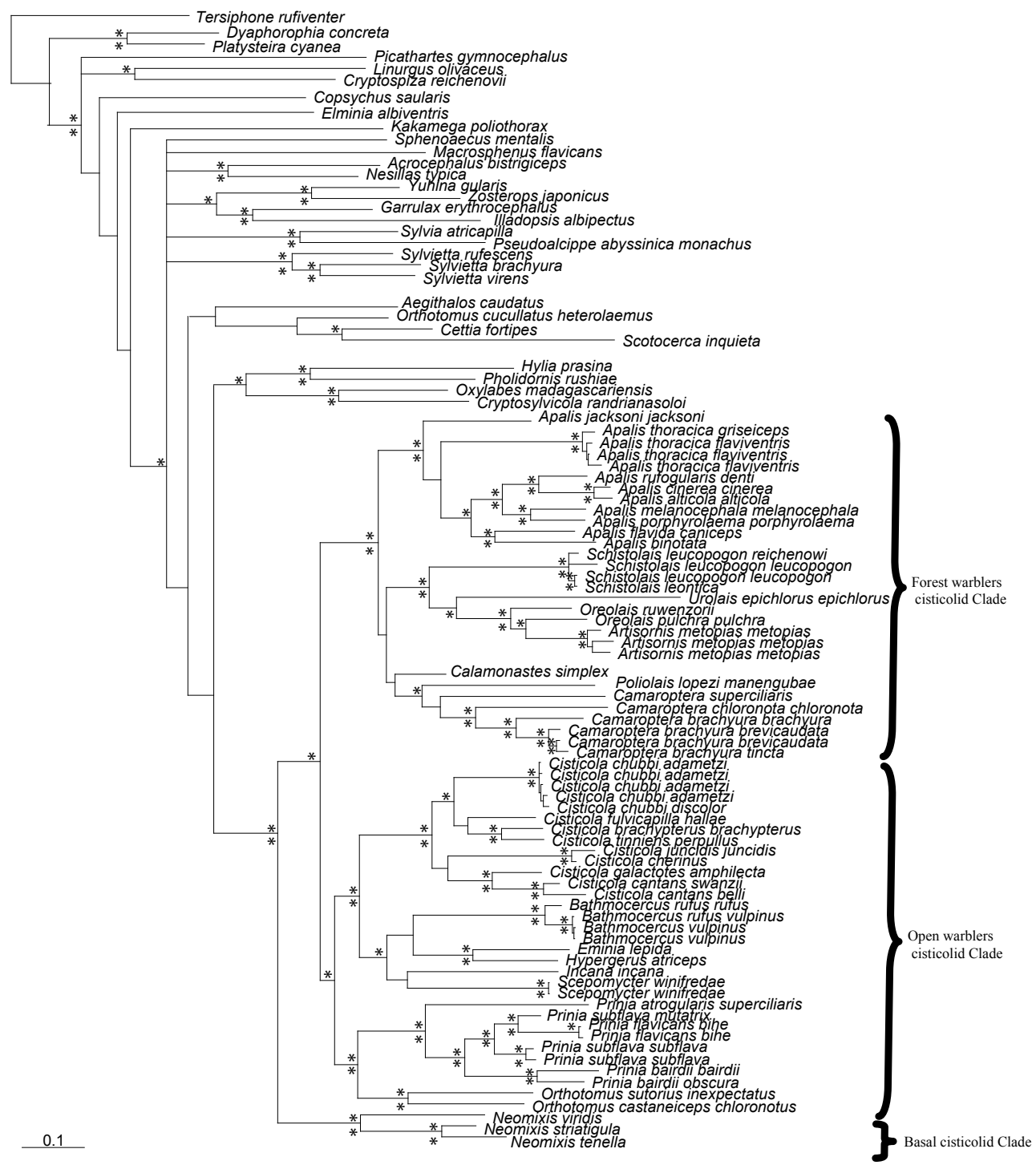

Fig. (1). Bayesian inference tree (mean log-likelihood value $=31103.21 \mathrm{SD}= \pm 2.89$ ) obtained from the mitochondrial ND2 sequences under a GTR + I + G model of sequence evolution. Asterisks above the nodes indicate posterior probabilities $(\geq 0.95)$ and those below, PhyML bootstrap values $(\geq 0.70)$. Base frequencies: $\mathrm{A}=0.40040, \mathrm{C}=0.36705, \mathrm{G}=0.06865, \mathrm{~T}=0.16389$, revmatrix $=0.20382,6.06480,0.32130$, $0.21098,3.24139, \alpha=0.688, \mathrm{I}=0.26$ (estimated from PhyML) and Maximum likelihood tree $(-\ln =24286.39)$ obtained from the mitochondrial ND2 gene is not shown.

tions (3000 trees) were discarded ('burn-in' period) and posterior probabilities (PP) were estimated from the remaining sampled generations. Four independent Bayesian runs initiated from random starting trees were performed for each dataset. Log-likelihood values and posterior probabilities across the four runs were also checked to warrant that chains had reached stationarity. For the combined Bayesian analysis, we used the selected models in a partitioned analysis (genes and codon positions) with the "unlink" command.

The topologies and nodal support obtained from different models were compared to detect incongruences. A node was considered to be supported if recovered with greater than $70 \%$ for bootstrap support [31] or with a posterior probability greater than 0.95 [32].

\section{Analysis of Time of Divergence}

For the diversification, we used the same method and calibration point already published in Zoologica Scripta [14] and in Journal of Avian Biology [33].

Thus, we used a Bayesian approach for estimates of divergence time using the MULTIDISTRIBUTE Software package $[34,35]$. Our aim was to establish firstly the time of separation between other passeridan taxa and the cisticolid clade; secondly, we aimed to find time periods within the cisticolid clade in order to discuss the origin and the diversification of the cisticolid taxa in keeping with geological events which took place during the corresponding time periods. We performed dating analyses in a relative time frame 


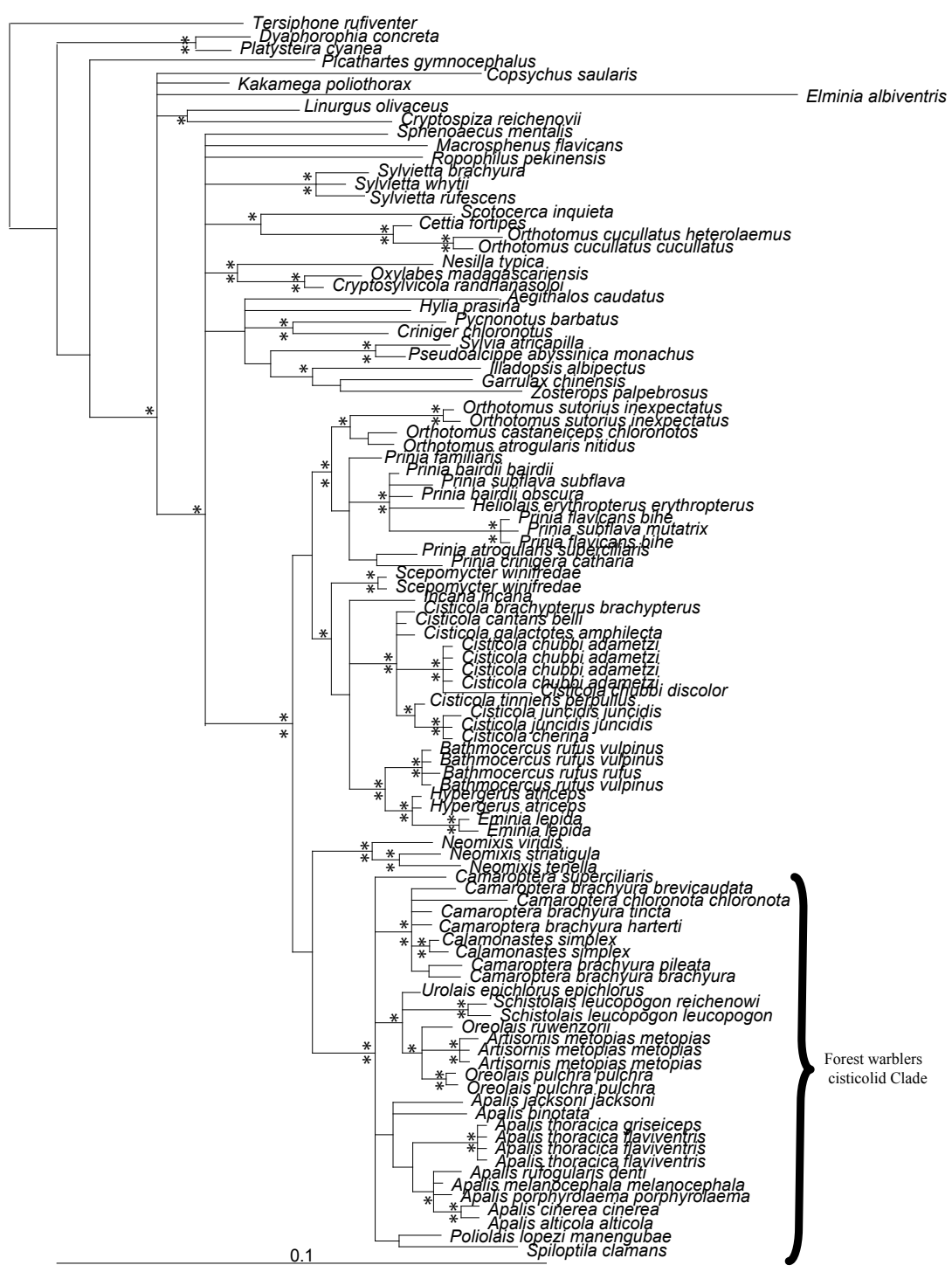

Fig. (2). Bayesian inference tree (mean log-likelihood value $=5552.09 \mathrm{sd}= \pm 0.78$ ) obtained from the nuclear myoglobin intron 2 sequences under a GTR $+\mathrm{I}+\mathrm{G}$ model of sequence evolution. Asterisks above the nodes indicate posterior probabilities $(\geq 0.95)$ and those below, PhyML bootstrap values $(\geq 0.70)$. Base frequencies: $\mathrm{A}=0.30032, \mathrm{C}=0.21796, \mathrm{G}=0.23139, \mathrm{~T}=0.25033$, revmatrix $=1.30146,4.28906$, $0.75131,1.39321,4.67474, \alpha=1.97, \mathrm{I}=0$ (estimated from PhyML) and Maximum likelihood tree (-ln $=3997.52)$ obtained from the myoglobin intron 2 is not shown.

work because no reliable fossil calibration point is available within this group; for this, we used a secondary calibration point derived from the previous study of Barker et al. [16] as well as a scale of time to convert time periods obtained. As a calibration point, we used the dispersal from Australasia (Picathartidae) (47.6 - 42.4). We set the basal node to time units and the distance between the tip and the root to 82 Myrs ( \pm 41 Myrs); this date corresponds to the estimation of the split between Acanthisittidae and other passerines [16]. And as priors, we adopted $0.0089 \pm 0.0089$ substitution per site per time unit for the rate at the root node (estimated using the procedure described in the multidivtime.readme file). The Bayesian topology obtained with the combined dataset (ND2 and myoglobin intron 2) was specified for dating analyses and we used lower and upper constraints to account for the standard deviation.

\section{RESULTS}

\section{Individual and Concatenated Datasets}

We obtained between 617 (Scotocerca inquieta MNHN) and $1041 \mathrm{bp}$ (majority of samples) for the ND2. Out of the full alignment of 1041 characters, $628(60.33 \%)$ were parsimony informative and $718 \quad(68.97 \%)$ variable. MrMODELTEST selected the GTR $+\mathrm{G}+\mathrm{I}$ as the best-fit model. For Bayesian inference, the average of the four runs resulted in $-\ln =31103.21$ with a $\mathrm{SD}= \pm 2.89$. Both $\mathrm{BI}$ and ML recovered the same topology which received high bootstrap and posterior probabilities (Fig. 1).

With the myoglobin intron 2, we obtained between 634 (Prinia flavicans bihe MNHN) and 640 bp (majority of samples). Indels were observed of which the most noteworthy 
Table 1. Primers Sequences Used for Amplification and Sequencing

\begin{tabular}{|c|c|c|}
\hline Primers & Sequence & References \\
\hline \hline L5219Met (ND2) & 5' CCC ATA CCC CGA AAA TGA TG 3' & Sorenson et al. (1999) \\
\hline INTL (ND2) & 5' TGR ATR GGV CTN AAY CAR AC 3' & Nguembock et al. (2007) \\
\hline INTH (ND2) & 5' GNG MGM GAT RAK GAG AAG GTC A 3' (2007) & Sorenson et al. (1999) \\
\hline H6313Trp (ND2) & 5' CTC TTA TTT AAG GCT TTG AAG GC 3' & Eberhard and Bermingham (2004) \\
\hline ATPase 6 (A8PWL) & 5' CCTGAACCTGACCATGAAC 3' & Eberhard and Bermingham (2004) \\
\hline ATPase 6 (CO3HMH) & 5' CACATAGTRGACCCCAGCCCATG 3' & Chesser (1999) \\
\hline L10755 (ND3) & 5' GACTTCCAATCTTTAAAATCTGG 3' (1999) \\
\hline H11151 (ND3) & 5' GATTTGTTGAGCCGAAATCAAC 3' & Slade et al. (1993) \\
\hline MYO2 (Myoglobin) & 5' GCCACCAGGCACAAGAAGATCCC 3' & Nguembock et al. (2007) \\
\hline MYO2IntF & 5' TRA GAC CCA TAA AAC TAA GTG 3' & Nguembock et al. (2007) \\
\hline MYO3IntR & 5' TGA TCT GCT TCA TGA CCT T 3' & Heslewood et al. (1998), modified \\
\hline MYO3F (Myoglobin) & 5' GCAAGGACCTTGATAATGACTT 3' & \\
\hline
\end{tabular}

Table 2. The Most Noteworthy Indels Observed in the Myoglobin Intron 2

\begin{tabular}{|c|c|c|}
\hline Types of indel identified & Total length of the indels & Taxa sharing each of the different indel \\
\hline 1 - autapomorphic deletion & seven bases & representatives of Orthotomus \\
\hline 3 - synapomorphic deletion & seven bases & Prinia bairdii, Prinia subflava and Heliolais erythropterus \\
\hline 4 - autapomorphic deletion & seven bases & representatives of Prinia flavicans \\
\hline 6 - synapomorphic deletion & four bases & members of the Asiatic prinias \\
\hline 7 - autapomorphic deletion & two bases & samples of Eminia lepida \\
\hline 8 - autapomorphic deletion & one base & samples of Hypergerus atriceps \\
\hline 9 - synapomorphic insertion & three bases & Oreolais and Artisornis \\
\hline 12 - autapomorphic insertion & one base & members of Artisornis metopias \\
\hline
\end{tabular}

are indicated in the Table 2 . The aligned myoglobin sequences comprised 640 characters, of which $220(34.37 \%)$ and $406(63.44 \%)$ were parsimony informative and variable, respectively. MrMODELTEST designated the GTR + G + I as the best-fit model. Parameters were estimated by PhyML and are given in detail in the legend of the Fig. (2). For Bayesian inference, the average of the four runs resulted in $\ln =5552.09(\mathrm{sd}= \pm 0.78)$. Both $\mathrm{ML}$ and $\mathrm{BI}$ recovered the same topology which received moderate bootstrap and posterior probability support (Fig. 2).

We obtained between 485 (Bathmocercus rufus vulpinus ZMUC/CDI) and 684 bp (majority of samples) for the ATPase 6 . Out of the full alignment of 684 characters, 350 $(51.17 \%)$ and $381(55.7 \%)$ were parsimony informative and variable, respectively. MrMODELTEST selected the GTR + $\mathrm{G}+\mathrm{I}$ as the best-fit model. For Bayesian inference, the average of the four runs resulted in $-\ln =15183.45$ with a $S D= \pm$ 5.8. Both BI and ML recovered the same topology which received moderate bootstrap and posterior probability support (Fig. 3).

For the ND3, sequences length ranged from $226 \mathrm{bp}$ (Platysteira cyanea MNHN) to $351 \mathrm{bp}$ (majority of samples). Out of the full alignment of 351 characters, $192(54.7 \%)$ were parsimony informative and 218 (62.11\%) variable. MrMODELTEST designated the GTR $+\mathrm{G}+\mathrm{I}$ as the best-fit model. For Bayesian inference, the average of the four runs resulted in $-\ln =7909.51(\mathrm{sd}= \pm 5.14)$. Both $\mathrm{BI}$ and $\mathrm{ML}$ 


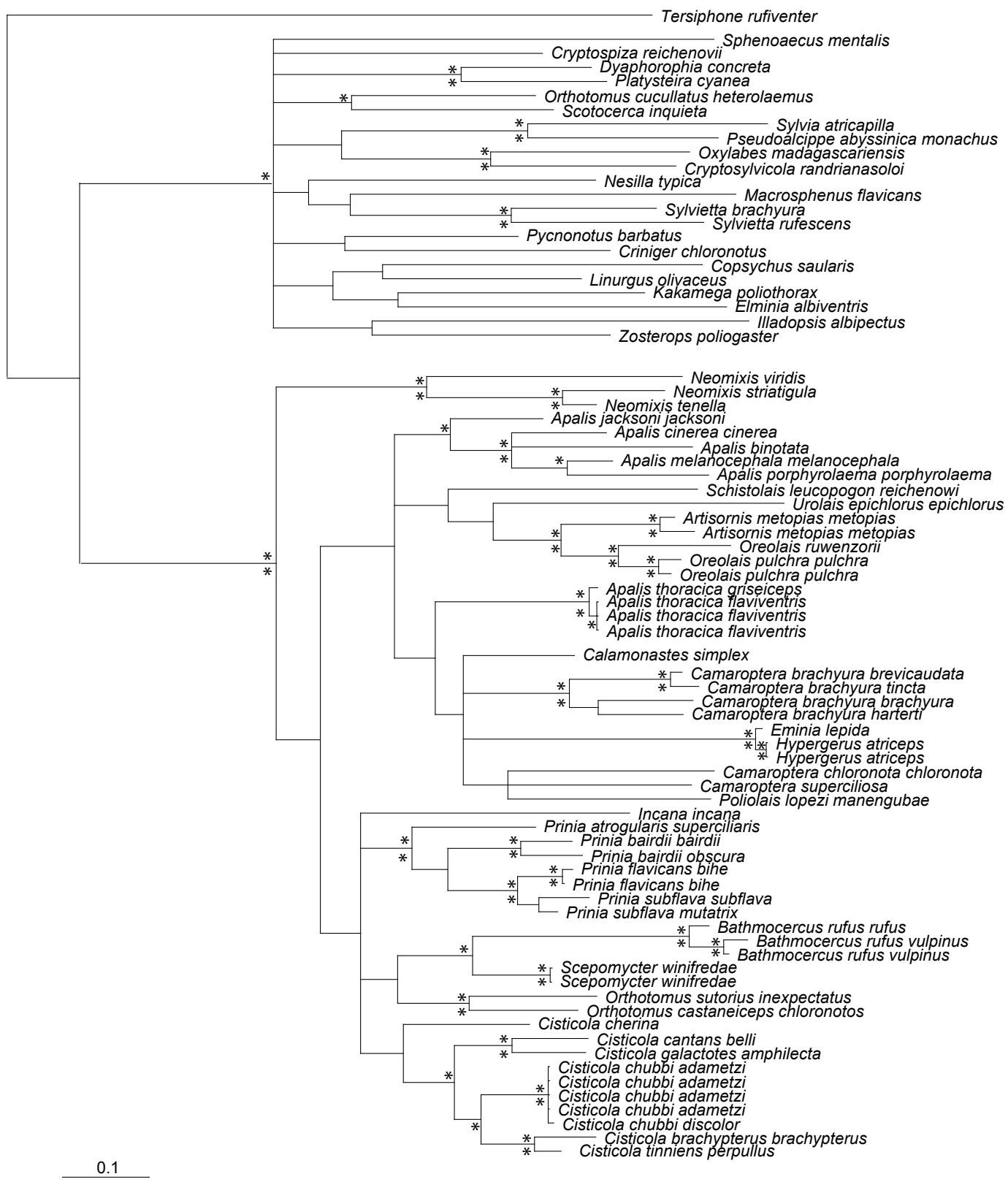

Fig. (3). Bayesian inference tree (mean log-likelihood value $=15183.45 \mathrm{sd}= \pm 5.8$ ) obtained from the mitochondrial ATPase 6 sequences under a GTR $+\mathrm{I}+\mathrm{G}$ model of sequence evolution. Asterisks above the nodes indicate posterior probabilities $(\geq 0.95)$ and those below, PhyML bootstrap values $(\geq 0.70)$. Base frequencies: $\mathrm{A}=0.37148, \mathrm{C}=0.40665, \mathrm{G}=0.06987, \mathrm{~T}=0.15200$, revmatrix $=0.16713,6.49400$, $0.40647,0.27873,4.11502, \alpha=0.496, \mathrm{I}=0.37$ (estimated from PhyML) and Maximum likelihood tree $(-\ln =12336.75279)$ obtained from the mitochondrial ATPase 6 gene is not shown.

recovered the same topology which received low bootstrap and posterior probability (tree not shown).

The concatenated dataset included 67 OTUs and $2723 \mathrm{bp}$. In Bayesian analyses, the concatenated dataset was partitioned by gene and codon position (ten partitions). The four independent runs with the concatenated dataset partitioned yielded a $50 \%$ majority consensus rule tree $(-\ln =49395.72 \pm$ 1.64, Fig. 4) where 36 out of 43 nodes of the ingroup taxa were supported by posterior probabilities of greater than 0.95 . Not surprisingly our results suggest that the tree based on mitochondrial protein-coding data (ATPase 6, ND2 and ND3) are more resolved than the tree based on nuclear intron sequences (myoglobin intron 2) but the topology based on the combined dataset is the best resolved. As a consequence, we focus the interpretation of our results almost mainly on the combined analysis.

\section{Phylogenetic Results}

No major conflict was observed between four individual genes used, or when compared to the concatenated dataset. The only incongruence involves the position of the basal insular Neomixis; ND2 and concatenated dataset suggest that Neomixis is basal within the cisticolid clade (Figs. 1 and 4) whereas myoglobin intron 2 also recovers a basal position of this genus but only for the "forest cisticolid" clade (Fig. 2). 
Table 3. Inferred Dates of Cisticolidae Divergences. Shown are the Average, Minimum, Maximum and Confidence Interval Values from Relaxed Molecular Clock Analysis Using the MULTIDISTRIBUTE Software Package from the Combined Dataset ND2 Gene and Myoglobin Intron 2. Numbered Nodes are Labelled on Fig. 5

\begin{tabular}{|c|c|c|c|c|c|}
\hline Node & Description & Minimum & Mean & Maximum & Confidence Interval (95\%) \\
\hline \hline 1 & Other passeridan taxa/Cisticolidae & 14.06 & 15.14 & 16.22 & $13.14-17.38$ \\
\hline 2 & Basal branch (Neomixis)/other cisticolid taxa & 12.51 & 13.55 & 14.59 & $11.63-15.7$ \\
\hline 3 & Open warblers clade/other cisticolid taxa & 11.9 & 12.92 & 13.94 & $11.02-15.01$ \\
\hline 4 & Orthotomus and Prinia/other taxa of the open warblers clade & 10.45 & 11.43 & 12.4 & $9.58-13.41$ \\
\hline 5 & Forest warblers clade/other cisticolid taxa & 10.03 & 10.99 & 11.95 & $9.2-12.98$ \\
\hline 6 & Orthotomus/Prinia & 8.42 & 9.34 & 10.26 & $7.65-11.24$ \\
\hline 7 & Poliolais, Calamonastes and Camaroptera/Urolais, & & & 9.76 & $7.16-10.74$ \\
\hline & Oreolais, Artisornis and Schistolais & 7.92 & 8.84 & 9.76 & $6.52-9.71$ \\
\hline 8 & Incana, Scepomycter and Bathmocercus/Cisticola & 7.2 & 8.01 & 8.82 & $6.31-9.83$ \\
\hline 10 & Schistolais/Urolais, Oreolais and Artisornis & 7.06 & 7.95 & 8.84 & 8.03 \\
\hline
\end{tabular}

According to our analyses, African warblers can be divided into two main clades, very well delimited with the most informative character partitions, ND2 (Fig. 1) as well as the combined analysis (Fig. 4) but differently recovered with other markers (Figs. 2 and 3). The DNA data give high support for the monophyly of the African warblers (Figs. 14). Of the eight multi-specific genera studied, only Orthotomus appears polyphyletic (Figs. 1-4). We will lean on the combined tree for the presentation of the two main clades except for some particular cases where we will use individual trees.

The "open cisticolid" clade, which includes nine currently recognized genera, is moderately supported with the ND2 and concatenated dataset (Figs. 1 and 4); this clade can be subdivided into two subclades. The first subclade consists of two genera, Orthotomus and Prinia, but Heliolais nests within the genus Prinia (Fig. 2). Within this subclade, Prinia flavicans appears close to $P$. subflava and $P$. bairdii is in a basal position to this group ( $P$. flavicans- $P$. subflava); within all prinias, the Asiatic sample always appears in a basal position. Orthotomus is polyphyletic by the separate position of O. cucullatus; O. sutorius, O. castaneiceps and O. atrogularis are grouped together and always appear closely related to Prinia (Figs. 1-4). The second subclade includes genera Cisticola, Scepomycter, Incana and Bathmocercus, but also Eminia and Hypergeris which are sister-taxa (Figs. 1-4). Cisticola always appears monophyletic but positions of Bathmocercus, Incana and Scepomycter remain unresolved in this study.

The "forest cisticolid" clade, which also comprises nine currently recognized genera, appears strongly supported (Figs. 1, 2 and 4). Within this clade, the montane genera Urolais, Schistolais, Oreolais and Artisornis form a subclade which is highly supported (Figs. 1 and 2); always within this subclade, Artisornis is close to Oreolais and these two genera are closely related to Urolais (Figs. 1 and 4). Schistolais appears in a basal position within this subclade (Fig. 1). Poliolais appears close to Camaroptera with the ND2 but not with the concatenated dataset (Figs. 1 and 4). Apalis is monophyletic in this study and A. thoracica appears in a basal position (Fig. 4).

\section{Dating Analysis Results}

Results of the dating analyses are presented in Table 3 and Fig. (5). The divergence of the cisticolid clade took place during the lower Miocene and the diversification of several genera within this group also took place during the same Miocene epoch. Four nodes are retrieved in the medium Miocene; they include diversifications of the basal branch (Neomixis), Orthotomus and Prinia genera, the "open cisticolid" clade as well as that of the "forest cisticolid" clade. Five nodes are retrieved in the upper Miocene; they include diversifications between taxa recognized as distinct genera [node 6 which represents the split between Orthotomus/Prinia; node 7 which represents the split between Schistolais/Urolais/Oreolais/Artisornis and Camaroptera/Calamonastes/Poliolais; node 8 which represents the split between Cisticola/Bathmocercus, Incana and Scepomycter; node 9 which represents the split between Schistolais/Urolais, Oreolais and Artisornis; node 10 which represents the split between Prinia (Asia)/Prinia (Africa)].

\section{DISCUSSION}

\section{Phylogeny of the African Warblers}

The phylogram obtained represents the best estimate of the relationships within the cisticolid clade and two main clades appear to be strongly supported.

In their phylogeny, Neomixis appears to be in a basal position and this result agrees with Nguembock et al. [3]. With regard to their sister-group neither Yellow Longbill nor Pycnonotidae nor Timaliidae taxa were found close to Afri- 


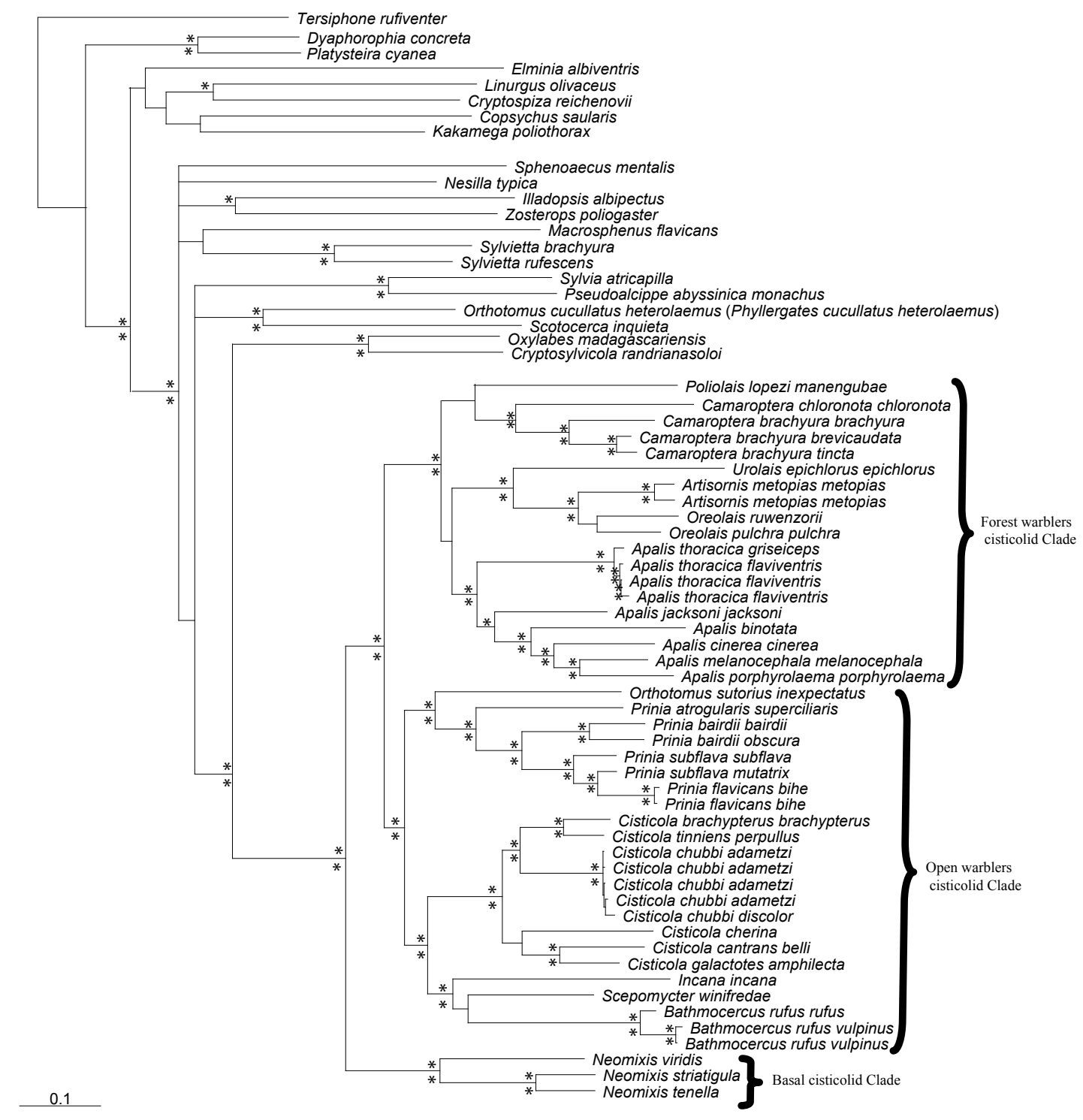

Fig. (4). Bayesian inference tree (mean log-likelihood value $=49395.72 \pm 1.64$ ) obtained from the combined dataset. The optimal parameterization as estimated by MrMODELTEST was assumed for each of ten partitions. Asterisks above the nodes indicate posterior probabilities $(\geq 0.95)$ and those below, PhyML bootstrap values $(\geq 0.70)$.

can warblers. In return two insular genera, Oxylabes and Cryptosylvicola, and two other taxa, Hylia prasina and Pholidornis rushiae, are well-supported as their sister-taxa in our ND2 tree but these two last taxa were lacking in our combined tree. Otherwise, some sylviid taxa, such as the genus Sylvietta, were lacking. Thus, their sister-group can be best considered as unresolved and we prefer to wait a further study to confidentially define them.

According to our main results, two clades of the African warblers are well-supported (Figs. 1-4). These two clades have been suggested by some authors $[2,11]$ but only this splitting was not based on molecular results. With regard to these authors, the cisticolid clade should be divided into two lineages and our results virtually retrieve their suggestion. The first includes the largest genus, Cisticola, a combination of African genera, Scepomycter, Bathmocercus, Incana, Heliolais, Eminia and Hypergerus, an Asian-African genus, Prinia, and an Asian genus, Orthotomus. The second in- cludes mainly African genera, Apalis, Schistolais, Urolais, Poliolais, Camaroptera, Calamonastes, Artisornis and Oreolais.

In reflection to our results, the splitting of the African warblers is almost in agreement with their living environment. Thus, African warblers included in the "open cisticolid" clade are almost all or less birds living in an open environment. These taxa often present brightly plumage colour $[2,11,36]$. Many of their members also show some common characteristics such as the nest structure which is usually enclosed, typically a ball with a side entrance at the top $[2,11,36]$.

Also, for taxa in the "forest cisticolid" clade, practically all these birds live in forest, in dense woodland or in more dense areas [2, 11, 36]. This "forest cisticolid" clade was already obtained by Sefc et al. [6], Alström et al. [8], Nguembock et al. [3] and Nguembock et al. [4]. This "forest 
cisticolid" clade appears as a natural lineage (Figs. 1-2). Most birds of this second clade generally present drab and cryptic plumage colour except for some taxa $[2,11,36]$.

\section{Some Novel Relationships}

Prior to this study and in accordance to several others [3$7,8,10,13,37]$, only eight of the 25 potential cisticolid genera from Dickinson [12] (Malcorus, Phragmacia, Oreophilais, Drymocichla, Phyllolais, Scotocerca, Urorhipis and Poliolais) have not been included in a very large molecular study including several other cisticolid taxa. Two of these, in this case Scotocerca and Poliolais, were included in this study.

The Streaked Scrub-warbler, Scotocerca inquieta, is a Paleartic monotypic species. Molecularly, it would have been studied by Sokolov [38] and has been formally studied by Nguembock et al. [10]. Preliminary results obtained by these authors have been confirmed by Alström et al. [37]. This species was previously placed in the cisticolid clade but according to our combined results (with $2716 \mathrm{bp}$ ), the Streaked Scrub-warbler is a cettid taxon (Fig. 4). Its isolated position was surprising at first glance but it is consistent with several morphological and ecological traits particularly in their juveniles.

Furthermore, the White-tailed Warbler, Poliolais lopezi, is a cisticolid taxon (Figs. 1, 2 and 4). This taxon is a monospecific genus endemic to the south-east of Nigeria, Cameroon highlands and the Bioko Island. It is a tiny forest warbler with a noteworthy fine and longish bill (B. Nguembock personal observation) and it inhabits mountain forest. According to [2], its affinities are uncertain and our study fails to find its sister-taxon.

Otherwise, for cisticolid taxa newly included in a molecular study (for instance Camaroptera superciliaris, Cisticola tinniens, Prinia flavicans, etc.), several new subspecific, inter-specific and inter-generic relationships appeared strongly supported (Figs. 1, 2, 3 and 4). Our study also confirms a strong relationship between the new cisticolid genus Oreolais sensu Nguembock et al. [4] and the genus Artisornis.

\section{Suggestion of the Taxonomic Change}

Our study included two tailorbirds (Artisornis metopias and Orthtotomus sutorius) which belong to the Cisticolidae family (Figs. 1-4). But it also includes an Asian species, Orthotomus cucullatus, which belongs to the Cettidae family. In the past, this species was included in the cisticolid clade but Alström et al. [8] had shown that it was close to Cettia. Nguembock et al. [3] had confirmed that this taxon was outgroup to a cisticolid clade. To avoid a muddle between this Cettia species and other Asian tailorbirds and waiting a large study including the type species of Orthotomus, O. sepium Horsf., 1821, we propose temporarily that the name Phyllergates cucullatus Temminck, 1836, be used for samples hitherto referred to Orthotomus cucullatus of the present study.

\section{Diversification of the Cisticolid Taxa}

Within the Passerida, Barker et al. [16] suggested that the diversification of most groups took place during the Miocene epoch. Like Barker et al. [16] concerning the two clades of the African warblers, our data suggest that they began their diversification during the transition Early-Middle Miocene epoch (Table 3). As a result, we think that it is not careful to suggest a hypothesis on the origin of the cisticolid clade because we did not confidentially resolve their sister-taxa.

Currently, cisticolid taxa are throughout the World but mainly in the African mainland. Their phylogram gives high support for their basal branch (the insular Neomixis). We estimated the time period of the insular basal divergence from other remaining continental cisticolid taxa at $13.55 \mathrm{Ma}$ and this date virtually corresponds to that estimated for the arrival of Carnivora to Madagascar [39]. These authors noted that these mammals probably emigrated from Africa. In accordance, the diversification of insular African warblers from continental Africa seems to be likely due to the fact that interchanges between some mammals ranging from Madagascar and Africa have equally been proved during this time frame [39]. The diversification of other cisticolid taxa would have involved dispersal and vicariance processes inside the African mainland.

The diversification of the "open cisticolid" clade would have occurred during the Middle Miocene. As for the diversification of the "forest cisticolid" lineage, it would have taken place during the Upper Miocene (Table 3). Within this "open cisticolid" clade, at least two intercontinental dispersal events, involving African and Asian mainlands, took place during the Upper Miocene epoch (Fig. 5). We note that these two intercontinental events coincide with our estimation of the divergence between the Asian Orthotomus and the African-Asian Prinia. Similarly, the diversification of other endemic African taxa took place during the same Neogene period (Fig. 5). According to [40], the mammalian faunal interchange between Afro-arabia and Eurasia took place less than 27 Myrs during the Neogene period. We think that the dispersal of some African taxa from Asia would have likely taken place during the same period.

For the diversification of endemic African taxa of the cisticolid clade during the Neogene period, it is well documented that a few geological changes have affected African biota. Particularly, there is a spread of grasslands corresponding to a contraction of the forest cover in the early Miocene, and an uplift of rift shoulders [41, 42]. Moreover, during the Neogene age, the uplift caused the isolation of eastern lowland forests from the main Guinea-Congolian rainforest block [43-46]. Furthermore, some palynological evidence suggests high rainforest biodiversity during the Miocene epoch in Africa [47, 48]. Due to the geological and climatic deterioration, the dispersal of cisticolid clades in Africa was very likely by the break-up of tropical forests during the Neogene period. Within the "forest cisticolid" lineage, our data suggest an early dispersal of genera Camaroptera, Calamonastes and Poliolais during the Late Miocene but the diversification of the genus Schistolais took place during the Upper Miocene (Fig. 5). 


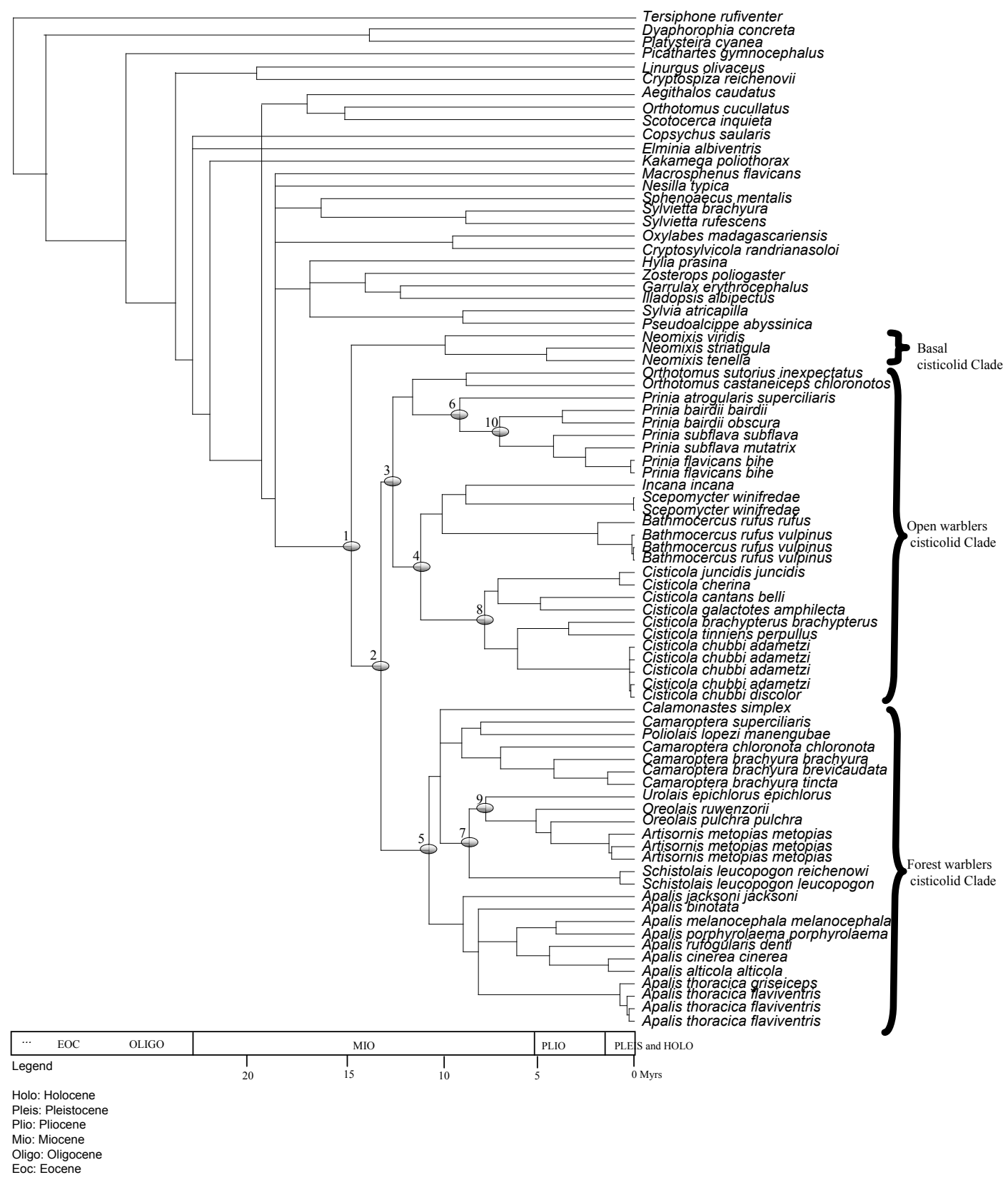

Fig. (5). Chronogram obtained from the Bayesian relaxed-clock method of Thorne et al. [35] and Thorne and Kishino [35] and using the Bayesian topology obtained with the combined dataset partitioned by gene and codon position. Numbered nodes labelled on figure correspond to the description given in Table 3.

\section{CONCLUSION}

The phylogeny of the African warblers appears more structured with our study. Firstly their monophyly as well as their basal branch are strongly supported. Secondly this group, which was included during long time in the paraphyletic Old World Warblers, comprises henceforth two main clades (the "open cisticolid" and the "forest cisticolid") with the "forest cisticolid" clade which appears to be a natural lineage. Within these clades, several new relationships are strongly supported.

The diversification of the African warblers in time and in space aligns oneself with previous results $[16,39,40]$. Thus, the diversification of their two clades would have taken place during the Neogene period. Otherwise in our study, we observe that dispersal and vicariance processes inside the African mainland would have influenced the diversification within the two cisticolid clades.

\section{ACKNOWLEDGEMENTS}

We are grateful to many people who contributed to the knowledge of the Cisticolidae family throughout the World. We thank Jon E. Ahlquist for their study which permitted to identify the cisticolid clade. We thank all researchers who took part in a study in keeping with this cisticolid clade: Burt L. Monroe, Jr., Alice Cibois, Thomas S. Schulenberg, Kris- 
tina M. Sefc, Robert B. Payne, Pamela Beresford, Peter G. Ryan, Per Alström, Per Sundberg, Jon Fjeldså, Eric Pasquet, Josep del Hoyo, Emil K. Urban, Hilary C. Fry, Stuart Keith, etc.. We are also grateful to various researchers, particularly Jon Fjeldså and Eric Pasquet, and institutions that caught and provided several samples or those whose sequences have been used in our study: FMNH, UMMZ, MNHN, ZMUC and all staff of WWF-Nyassosso (Cameroon). We wish to thank J. Lambourdière and C. Bonillo for their help during laboratory work (France). In additional, we thank several anonymous referees for their comments on an earlier version of this manuscript, particularly a few Anglophone researchers and students of the University of Yaounde I (Cameroon). We also thank the "Service de Systématique Moléculaire" of the "Muséum National d'Histoire Naturelle", the Génoscope "Consortium National de Recherche en Génomique" (France) and the Zoological research Laboratory of the University of Yaounde I (Cameroon) for their technical support.

\section{CONFLICT OF INTEREST}

The author(s) confirm that this article content has no conflicts of interest.

\section{ABBREVIATIONS}

$\begin{array}{lll}\text { Bp } & = & \text { base pairs } \\ \text { ATPase 6 } & = & \text { ATP synthase subunit 6 } \\ \text { ND2 } & = & \text { NADH dehydrogenase subunit 2 } \\ \text { ND3 } & = & \text { NADH dehydrogenase subunit 3 } \\ \text { BI } & = & \text { Bayesian Inference } \\ \text { ML } & = & \text { Maximum Likelihood } \\ \text { Myrs/Ma } & = & \text { Millions years } \\ \text { SD } & = & \text { Standard Deviation } \\ \text { OUT } & = & \text { Operational Taxonomic Unit }\end{array}$

\section{Annexe}

Annexe. Names of Taxa (Following Dickinson [12] and Several Recent Molecular Works), Family and Country for Individual Specimens, Museum Voucher or Tissue Numbers and the Length of DNA Sequences Used in This Study. Acronyms are: AMNH, American Museum of Natural History; FMNH, Field Museum of Natural History; NRM, Swedish Museum of Natural History; UMMZ, University of Michigan Museum of Zoology; MNHN, Museum National d'Histoire Naturelle; ZMUC, Zoological Museum of the University (Copenhagen)

\begin{tabular}{|c|c|c|c|c|c|c|c|}
\hline Species & Country & Family & Voucher & ATPase6 & ND2 & ND3 & Myoglobin \\
\hline \multicolumn{8}{|l|}{ Cisticolidae } \\
\hline Apalis alticola alticola & Tanzania & Cisticolidae & ZMUC 123398 & - & EU239793 & EU247893 & EU247917 \\
\hline Apalis binotata & Tanzania & Cisticolidae & ZMUC 133492 & JX259140 & EU239794 & EU247894 & EU247920 \\
\hline Apalis cinerea cinerea & Burundi & Cisticolidae & FMNH 358088 & JX259106 & DQ871370 & EU247904 & DQ871408 \\
\hline Apalis jacksoni jacksoni & Burundi & Cisticolidae & FMNH 358081 & - & DQ871371 & EU247905 & DQ871409 \\
\hline Apalis melanocephala melanocephala & Tanzania & Cisticolidae & ZMUC 129285 & JX259138 & EU239795 & EU247895 & EU247918 \\
\hline Apalis porphyrolaema porphyrolaema & Tanzania & Cisticolidae & ZMUC 123196 & JX259141 & EU239796 & EU247896 & EU247921 \\
\hline Apalis rufogularis denti & Kenya & Cisticolidae & MNHN68-1139 & - & DQ871387 & EU247907 & DQ871431 \\
\hline Apalis thoracica griseiceps & Tanzania & Cisticolidae & ZMUC 136606 & JX259139 & EU239797 & EU247897 & EU247919 \\
\hline Apalis thoracica flaviventris & Malawi & Cisticolidae & GA94334 & JX259146 & EU239798 & EU247898 & EU247922 \\
\hline Apalis thoracica flaviventris & Malawi & Cisticolidae & GA94354 & JX259147 & EU239799 & EU247899 & EU247923 \\
\hline Apalis thoracica flaviventris & Malawi & Cisticolidae & GA94346 & JX259148 & EU239800 & EU247900 & EU247924 \\
\hline Artisornis metopias metopias & Tanzania & Cisticolidae & ZMUC 119714 & - & DQ871363 & EU247910 & DQ871399 \\
\hline Artisornis metopias metopias & Tanzania & Cisticolidae & ZMUC 119915 & JX259099 & DQ871364 & EU247911 & DQ87140 \\
\hline Artisornis metopias metopias & Tanzania & Cisticolidae & FMNH 356778 & JX259115 & DQ871380 & EU247909 & DQ871418 \\
\hline Bathmocercus rufus vulpinus & Uganda & Cisticolidae & $\mathrm{ZMUC/CDI}$ & JX259096 & DQ871359 & JX259214 & DQ871395 \\
\hline Bathmocercus rufus vulpinus & Uganda & Cisticolidae & ZMUC/CD9 & - & DQ871360 & JX259215 & DQ871396 \\
\hline Bathmocercus rufus vulpinus & Uganda & Cisticolidae & FMNH 385102 & JX259108 & DQ871373 & JX259219 & DQ871411 \\
\hline Bathmocercus rufus rufus & Gabon & Cisticolidae & FMNH 389391 & JX259109 & DQ871374 & JX259220 & DQ871412 \\
\hline Calamonastes simplex & Kenya & Cisticolidae & ZMUC & JX259119 & JX259192 & - & DQ871404 \\
\hline Calamonastes simplex & Kenya & Cisticolidae & ZMUC & - & - & - & DQ871422 \\
\hline
\end{tabular}




\begin{tabular}{|c|c|c|c|c|c|c|c|}
\hline Camaroptera brachyura brachyura & South Africa & Cisticolidae & FMNH 390141 & JX259110 & DQ871375 & JX259221 & DQ871413 \\
\hline Camaroptera brachyura tincta & Guinea & Cisticolidae & MNHN 40-14 & JX259137 & JX259199 & JX259240 & JX259173 \\
\hline Camaroptera brachyura brevicaudata & Cameroon & Cisticolidae & MNHN & JX259090 & DQ871357 & EU247912 & DQ871389 \\
\hline Camaroptera chloronota chloronota & Cameroon & Cisticolidae & MNHN & JX259104 & DQ871369 & EU247913 & DQ871407 \\
\hline Camaroptera brachyura harterti & Angola & Cisticolidae & GA59033 & JX259150 & - & EU247901 & EU247925 \\
\hline Camaroptera superciliaris & - & Cisticolidae & MNHN & JX259105 & JX259191 & - & JX259163 \\
\hline Cisticola brachypterus brachypterus & Cameroon & Cisticolidae & MNHN & JX259092 & JX259189 & JX259211 & DQ871391 \\
\hline Cisticola cantans belli & Uganda & Cisticolidae & FMNH 391762 & JX259111 & DQ871376 & JX259222 & DQ871414 \\
\hline Cisticola cherina & Madagascar & Cisticolidae & FMNH 352929 & JX259112 & DQ871377 & JX259223 & DQ871415 \\
\hline Cisticola chubbi adametzi & Cameroon & Cisticolidae & MNHN 40-6 & JX259132 & JX259194 & JX259235 & JX259168 \\
\hline Cisticola chubbi adametzi & Cameroon & Cisticolidae & MNHN 40-10 & JX259133 & JX259195 & JX259236 & JX259169 \\
\hline Cisticola chubbi adametzi & Cameroon & Cisticolidae & MNHN 40-11 & JX259134 & JX259196 & JX259237 & JX259170 \\
\hline Cisticola chubbi adametzi & Cameroon & Cisticolidae & MNHN 40-12 & JX259135 & JX259197 & JX259238 & JX259171 \\
\hline Cisticola chubbi discolor & Cameroon & Cisticolidae & MNHN & JX259159 & JX259207 & JX259252 & JX259186 \\
\hline Cisticola galactotes amphilecta & Uganda & Cisticolidae & FMNH 346443 & JX259113 & DQ871378 & JX259224 & DQ871416 \\
\hline Cisticola tinniens perpullus & Angola & Cisticolidae & GA59061 & JX259149 & - & JX259245 & JX259178 \\
\hline Eminia lepida & Kenya & Cisticolidae & ZMUC & JX259122 & - & JX259229 & DQ871425 \\
\hline Eminia lepida & - & Cisticolidae & MNHN & - & - & JX259227 & JX259164 \\
\hline Hypergerus atriceps & Cameroon & Cisticolidae & MNHN & JX259120 & AF407053 & - & DQ871426 \\
\hline Hypergerus atriceps & - & Cisticolidae & - & JX259123 & - & - & JX259165 \\
\hline Incana incana & Socotra & Cisticolidae & MNHN & JX259103 & DQ871368 & JX259218 & DQ871406 \\
\hline Neomixis striatigula & Madagascar & Cisticolidae & FMNH & JX259124 & DQ871383 & JX259230 & DQ871427 \\
\hline Neomixis tenella & Madagascar & Cisticolidae & FMNH & JX259125 & DQ871384 & JX259231 & DQ871428 \\
\hline Neomixis viridis & Madagascar & Cisticolidae & FMNH & JX259126 & DQ871385 & JX259232 & DQ871429 \\
\hline Oreolais pulchra pulchra & Kenya & Cisticolidae & MNHN & JX259129 & DQ871388 & EU247906 & DQ871432 \\
\hline Oreolais pulchra pulchra & Cameroon & Cisticolidae & MNHN 40-95 & JX259155 & - & JX259248 & JX259182 \\
\hline Oreolais ruwenzorii & Uganda & Cisticolidae & FMNH 355837 & JX259107 & DQ871372 & EU247908 & DQ871410 \\
\hline Orthotomus castaneiceps chloronotus & Philippines & Cisticolidae & FMNH 350975 & JX259114 & DQ871379 & - & DQ871417 \\
\hline Orthotomus sutorius inexpectatus & China, Yunnan & Cisticolidae & MNHN & JX259100 & DQ871365 & EU686375 & DQ871401 \\
\hline Poliolais lopezi manengubae & Cameroon & Cisticolidae & MNHN 40-13 & JX259136 & JX259198 & JX259239 & JX259172 \\
\hline Prinia atrogularis superciliaris & China, Yunnan & Cisticolidae & MNHN & JX259101 & DQ871366 & JX259217 & DQ871402 \\
\hline Prinia bairdii bairdii & Cameroon & Cisticolidae & MNHN & JX259093 & DQ871358 & JX259212 & DQ871392 \\
\hline Prinia bairdii obscura & Uganda & Cisticolidae & FMNH 355824 & JX259117 & DQ871381 & JX259226 & DQ871420 \\
\hline Prinia flavicans bihe & Angola & Cisticolidae & W17420 & JX259142 & JX259200 & JX259241 & JX259174 \\
\hline Prinia flavicans bihe & Angola & Cisticolidae & W7418 & JX259143 & JX259201 & JX259242 & JX259175 \\
\hline Prinia subflava subflava & Cameroon & Cisticolidae & MNHN & JX259102 & DQ871367 & EU247915 & DQ871405 \\
\hline Prinia subflava mutatrix & Malawi & Cisticolidae & GA84821 & JX259144 & JX259202 & JX259243 & JX259176 \\
\hline Scepomycter winifredae & Tanzania & Cisticolidae & ZMUC/JK2 & JX259097 & DQ871361 & JX259216 & DQ871397 \\
\hline Scepomycter winifredae & Tanzania & Cisticolidae & ZMUC/LHA1 & JX259098 & DQ871362 & - & DQ871398 \\
\hline Schistolais leucopogon reichenowi & Uganda & Cisticolidae & FMNH 391767 & JX259118 & DQ871382 & - & DQ871421 \\
\hline
\end{tabular}




\begin{tabular}{|c|c|c|c|c|c|c|c|}
\hline Schistolais leucopogon leucopogon & Cameroon & Cisticolidae & MNHN 40-7 & - & EU239801 & EU247902 & EU247926 \\
\hline Urolais epichlorus epichlorus & Cameroon & Cisticolidae & MNHN 40-5 & - & EU239802 & EU247903 & EU247927 \\
\hline \multicolumn{8}{|c|}{ Cisticolidae (Genbank and Embl-bank sequences) } \\
\hline Apalis flavida caniceps & Gambia & Cisticolidae & UMMZ 235.837 & AY136597 & & & \\
\hline Camaroptera brachyura pileata & Tanzania & Cisticolidae & ZMUC 01986 & & DQ008549 & & \\
\hline Camaroptera brachyura brevicaudata & Gambia & Cisticolidae & UMMZ A339 & & AF407052 & & \\
\hline Cisticola cantans swanzii & Gambia & Cisticolidae & UMMZ 235.853 & AY136593 & & & \\
\hline Cisticola fulvicapilla hallae & Zimbabwe & Cisticolidae & UMMZ A761 & & AF407051 & & \\
\hline Cisticola juncidis juncidis & France & Cisticolidae & MNHN & & & JX259190 & DQ871403 \\
\hline Cisticola juncidis juncidis & Italia & Cisticolidae & NRM & & DQ008544 & & \\
\hline Eminia lepida & Kenya & Cisticolidae & UMMZ 211635 & & AY136598 & & \\
\hline Heliolais erythropterus erythropterus & Niger & Cisticolidae & NRM & & DQ008550 & & \\
\hline Hypergerus atriceps & Gambia & Cisticolidae & UMMZ A345 & & AF407053 & & \\
\hline Orthotomus atrogularis nitidus & Vietnam & Cisticolidae & NRM & & DQ008543 & & \\
\hline Orthotomus sutorius inexpectatus & Thailand & Cisticolidae & NRM & & DQ008542 & & \\
\hline Prinia crinigera catharia & Myanmar & Cisticolidae & NRM & & DQ008540 & & \\
\hline Prinia familiaris & Indonesia & Cisticolidae & NRM 20046794 & DQ008541 & & & \\
\hline Prinia subflava subflava & Gambia & Cisticolidae & UMMZ 235.854 & AY136594 & & & \\
\hline Schistolais leontica & Guinea & Cisticolidae & UMMZ 235.855 & AY136595 & & & \\
\hline Schistolais leucopogon leucopogon & Cameroon & Cisticolidae & UMMZ 232.418 & AY136596 & & & \\
\hline Spiloptila clamans & Mauritania & Cisticolidae & NRM & DQ008546 & & & \\
\hline \multicolumn{8}{|l|}{ Other groups included in this study } \\
\hline Aegithalos caudatus & - & Aegithalidae & UMMZ A571 & & AY136588 & & \\
\hline Aegithalos caudatus & Sweden & Aegithalidae & NRM 976089 & & AY228281 & & \\
\hline Cettia fortipes & - & Cettidae & - & & DQ125976 & DQ125948 & \\
\hline Cettia fortipes & - & Cettidae & KIZ05353 & & DQ837490 & & \\
\hline Copsychus saularis & Thailand & Muscicapidae & MNHN & JX259121 & DQ125977 & JX259228 & DQ871424 \\
\hline Criniger chloronotus & Cameroon & Pycnonotidae & MNHN & JX259157 & - & JX259250 & JX259184 \\
\hline Cryptospiza reichenovii & Cameroon & Estrildidae & MNHN & JX259158 & JX259206 & JX259251 & JX259185 \\
\hline Dyaphorophyia concreta & Cameroon & Platysteiridae & MNHN & JX259160 & JX259208 & JX259253 & JX259187 \\
\hline Elminia albiventris & Cameroon & Stenostiridae & MNHN 40-63 & JX259151 & EU652712 & JX259246 & JX259179 \\
\hline Hylia prasina & - & Cettidae & LSUMZ 163337 & AY136606 & DQ125955 & & \\
\hline Illadopsis albipectus & Cameroon & Timaliidae & MNHN & JX259153 & JX259205 & EU686336 & JX259181 \\
\hline Kakamega poliothorax & Cameroon & Timaliidae & MNHN 40-4 & JX259131 & EU686330 & EU686374 & EU686289 \\
\hline Linurgus olivaceus & Cameroon & Fringillidae & MNHN 40-8 & EU880940 & EU652706 & EU881006 & EU669964 \\
\hline Orthotomus cucullatus cucullatus & Indonesia & Cettidae & NRM & & DQ008566 & & \\
\hline Orthotomus cucullatus heterolaemus & Philippines & Cettidae & FMNH 357483 & JX259116 & DQ125999 & JX259225 & DQ871419 \\
\hline Picathartes gymnocephalus & Liberia & Picathartidae & AMNH AC350 & & DQ125989 & AY228314 & \\
\hline Pholidornis rushiae & - & Paridae & ZFMK 61.1422 & & AY136586 & & \\
\hline Platysteira cyanea & Cameroon & Platysteiridae & MNHN & JX259161 & JX259209 & $\mathrm{JX} 259254$ & JX259188 \\
\hline
\end{tabular}




\begin{tabular}{|c|c|c|c|c|c|c|c|}
\hline Pseudoalcippe abyssinica monachus & Cameroon & Timaliidae & MNHN 40-75 & JX259154 & EU652717 & EU686376 & EU669975 \\
\hline Pycnonotus barbatus inornatus & Cameroon & Pycnonotidae & MNHN & JX259156 & - & JX259249 & JX259183 \\
\hline Rhopophilus pekinensis & China & Timaliidae & NRM & & DQ008538 & & \\
\hline Scotocerca inquieta & - & Cettidae & MNHN & JX259145 & JX259203 & JX259244 & JX259177 \\
\hline Sylvia atricapilla & Israel & Timaliidae & - & NC_010228 & NC_010228 & NC_010228 & \\
\hline Sylvia atricapilla & Sweden & Timaliidae & NRM 976380 & & AY887727 & & \\
\hline Zosterops japonicus & - & Zosteropidae & GLGS2247 & & DQ837491 & & \\
\hline Zosterops japonicus & - & Zosteropidae & MNHN & & DQ861968 & & \\
\hline Zosterops palpebrosus & - & Zosteropidae & MNHN & & DQ125973 & & \\
\hline Zosterops poliogaster & Kenya & Zosteropidae & ZMUC 08629 & DQ328433 & & & \\
\hline \multicolumn{8}{|l|}{ Sylviidae } \\
\hline Acrocephalus bistrigiceps & Japan & Sylviidae & UMMZ 234.837 & AY136601 & & & \\
\hline Cryptosylvicola randrianasoloi & - & Sylviidae & MNHN & JX259128 & - & JX259233 & JX259166 \\
\hline Garrulax chinensis & - & Sylviidae & NRM 20046790 & DQ008536 & & & \\
\hline Garrulax erythrocephalus & - & Sylviidae & MNHN & & DQ861987 & & \\
\hline Garrulax squamatus & - & Sylviidae & GLGS1833 & & DQ837502 & & \\
\hline Macrosphenus flavicans & Cameroon & Sylviidae & MNHN & JX259094 & DQ125997 & JX259213 & DQ871393 \\
\hline Nesilla typica & - & Sylviidae & MNHN & JX259130 & JX259193 & JX259234 & JX259167 \\
\hline Oxylabes madagascariensis & - & Sylviidae & MNHN & JX259089 & - & JX259210 & JX259162 \\
\hline Sphenoaecus mentalis & Cameroon & Sylviidae & MNHN & JX259091 & DQ125998 & EU247916 & DQ871390 \\
\hline Sylvietta brachyura & - & Sylviidae & MNHN & JX259095 & DQ126001 & - & DQ871394 \\
\hline Sylvietta rufescens & Malawi & Sylviidae & MNHN & JX259127 & DQ871386 & - & DQ871430 \\
\hline Sylvietta virens & Gambia & Sylviidae & UMMZ 235.840 & AY136602 & & & \\
\hline Sylvietta whytii & Kenya & Sylviidae & ZMUC & & DQ871423 & & \\
\hline Yuhina brunneiceps & - & Sylviidae & NTNUT0620 & & DQ837501 & & \\
\hline Yuhina gularis & - & Sylviidae & MNHN & & DQ861973 & & \\
\hline \multicolumn{8}{|l|}{ Outgroup } \\
\hline Tersiphone rufiventer & Cameroon & Monarchidae & MNHN 40-64 & JX259152 & JX259204 & JX259247 & JX259180 \\
\hline
\end{tabular}

\section{REFERENCES}

[1] Sibley CG, Ahlquist JE. Phylogeny and classification of birds: a study in molecular evolution. New Haven, CT: Yale University Press, 1990.

[2] Ryan PG. Family Cisticolidae (cisticolas and allies). In: del Hoyo J, Elliott A, Christie DA, Eds. Handbook of the Birds of the World. Volume 11. Barcelona: Lynx 2006; pp. 378-419.

[3] Nguembock B, Fjeldså J, Tillier A, Pasquet E. A phylogeny for the Cisticolidae (Aves: Passeriformes) based on nuclear and mitochondrial DNA sequence data, and a re-interpretation of a unique nestbuilding specialization. Mol Phylogenet Evol 2007; 42: 272-86.

[4] Nguembock B, Fjeldså J, Couloux A, Cruaud C, Pasquet E. Polyphyly of the genus Apalis and a new generic name for the species pulchra and ruwenzorii. Ibis 2008a; 150: 756-65.

[5] Cibois A, Pasquet E, Schulenberg TS. Molecular systematics of the malagasy babblers (Passeriformes: Timaliidae) and warblers (Passeriformes: Sylviidae), based on cytochrome b and 16S rRNA sequences. Mol Phylogenet Evol 1999; 13: 581-95.

[6] Sefc KM, Payne RB, Sorenson MD. Phylogenetics relationships of African sunbird-like warblers: Moho (Hypergerus atriceps), green

Hylia (Hylia prasina), and Tit-hylia (Pholidornis rushiae). Ostrich 2003; 74: 8-17.

[7] Beresford P, Barker FK, Ryan PG, Crowe TM. African endemics span the tree of songbirds (Passeri): molecular systematics of several evolutionary 'enigmas'. Proc Biol Sci 2005; 272: 849-58.

[8] Alström P, Ericsson PGP, Olsson U, Sundberg P. Phylogeny and classification of the avian superfamily Sylvioidea. Mol Phylogenet Evol 2006; 38: 381-97

[9] Johansson US, Fjeldså J, Bowie RCK. Phylogenetic relationships within Passerida (Aves: Passeriformes): a review and a new molecular phylogeny based on three nuclear intron markers. Mol Phylogenet Evol 2008 ; 48: 858-76.

[10] Nguembock B. Etude phylogénétique et biogéographique de l'avifaune forestière des montagnes de l'Ouest du Cameroun. Ph.D. dissertation. France: University of Paris VI 2008c.

[11] del Hoyo J, Elliott A, Christie DA. Family Cisticolidae (cisticolas and allies). In: del Hoyo J, Elliott A, Christie DA, Eds. Handbook of the birds of the World. Vol. 11. Barcelona: Lynx 2006; pp. 42090 .

[12] Dickinson EC. The howard and moore complete checklist of the birds of the World. $3^{\text {rd }}$ ed. NJ, USA: Princeton University Press 2003. 
[13] Cibois A, Slika B, Schulenberg TS, Pasquet E. An endemic radiation of Malagasy songbirds is revealed by mitochondrial DANN sequence data. Evolution 2001; 55: 1198-206.

[14] Nguembock B, Fjeldså J, Cruaud C, Pasquet E. Molecular phylogenetic analysis of all members of the genus Elminia confirms their presence within the Stenostiridae clade. Zool Scr 2008b; 37: 591-602.

[15] Irestedt M, Ohlson JL. The division of the major songbird radiation into Passerida and 'core Corvoidea' (Aves: Passeriformes) - the species trees vs. gene trees. Zool Scr 2008; 37: 305-13.

[16] Barker FK, Cibois A, Schikler P, Feinstein J, Cracraft J. Phylogeny and diversification of the largest avian radiation. Proc Natl Acad Sci USA 2004; 101: 11040-5.

[17] Winnepenninckx B, Backeljau T, De Wachter R. Extraction of high molecular weight DNA from mollusks. Trends Genet 1993; 9: 407.

[18] Eberhard JR, Bermingham E. Phylogeny and biogeography of the Amazona ochrocephala (Aves: Ptsittacidae) complex. Auk 2004; 121: 318-32.

[19] Chesser RT. Molecular systematics of the rhinocryptic genus Pteroptochos. Condor 1999; 101: 439-46.

[20] Sorenson MD, Ast JC, Dimcheff DE, Yuri T, Mindell DP. Primers for a PCR-based approach to mitochondrial genome sequencing in birds and other vertebrates. Mol Phylogenet Evol 1999; 12: 105-14.

[21] Heslewood MM, Elphinstone MS, Tidemann SC, Baverstock PR. Myoglobin intron variation in the Gouldian Finch Erythrura gouldiae assessed by temperature gradient gel electrophoresis. Electrophoresis 1998; 19: 142-51.

[22] Slade RW, Moritz C, Heideman A, Hale PT. Rapid assessment of single-copy nuclear DNA variation in diverse species. Mol Ecol 1993; 2: 359-73.

[23] Sorenson MD, Quinn TW. Numts: a challenge for avian systematics and population biology. Auk 1998; 115: 214-21.

[24] Hall T. BioEdit. Available from: http://www.mbio.ncsu.edu/Bio Edit/bioedit.html . 2001.

[25] Guindon S, Gascuel O. A simple, fast, and accurate algorithm to estimate large phylogenies by maximum likelihood. Syst Biol 2003; 52: 696-704.

[26] Huelsenbeck JP, Ronquist F. MrBayes: a program for the Bayesian inference of phylogeny. Version 3.0b4. Available from: $<\mathrm{http}: / /$ morphbank.ebc.uu.se/mrbayes >. 2003.

[27] Akaike H. Information theory as an extension of the maximum likelihood principle. In: Petrov BN, Csaki F, Eds. Theory. Second International Symposium on Information. Budapest: Akademiai Kiado 1973.

[28] Nylander JAA. MrModeltest2. Available from: http://www.ebc.uu. se/systzoo/staV/nylander.html . 2004.

[29] Swofford DL. PAUP: Phylogenetic analysis using parsimony (and other methods) Version 4.0b. Sunderland, MA: Sinauer Associates 2001.

[30] Felsenstein J. Confidence limits on phylogenies: an approach using the bootstrap. Evolution 1985; 39: 783-91.
[31] Hillis DM, Bull JJ. An empirical test of bootstrapping as a method for assessing confidence in phylogenetic analysis. Syst Biol 1993; 42: $182-92$.

[32] Huelsenbeck JP, Ronquist F. MrBayes: Bayesian inference of phylogeny. Bioinformatics 2001; 17: 754-5.

[33] Nguembock B, Cibois A, Bowie RCK, Cruaud C, Pasquet E. Phylogeny and biogeography of the genus Illadopsis (Passeriformes, Timaliidae) reveal the complexity of diversification of some African taxa. J Avian Biol 2009; 40: 113-25.

[34] Thorne JL, Kishino H, Painter IS. Estimating the rate of evolution of the rate of molecular evolution. Mol Biol Evol 1998; 15: 164757.

[35] Thorne JL, Khisino H. Divergence time and evolutionary rate estimation with multilocus data. Syst Biol 2002; 51: 689-702.

[36] Urban EK, Fry CH, Keith S. The birds of Africa. Volume 5. London: Academic Press 1997.

[37] Alström P, Fjeldsa J, Fregin S, Olsson U. Gross morphology betrays phylogeny: the Scrub Warbler Scotocerca inquieta is not a cisticolid. Ibis 2011; 153: 87-97.

[38] Sokolov EP. The taxonomy and relationship of the Scrub Warbler Scotocerca inquieta. Unpublished.

[39] Yoder AD, Burns MM, Zehr S, et al. Single origin of Malagasy Carnivora from an African ancestor. Nature 2003; 421: 734-7.

[40] Kappelman J, Rasmussen DT, Sanders WJ, et al. Oligocene mammals from Ethiopia and faunal exchange between Afro-Arabia and Eurasia. Nature 2003; 426: 549-52.

[41] Reuilly TA, Raja PKS, Musset AE, Brock A. The paleomagnetism of late Cenozoic volcanic rocks from Kenya and Tanzania. Geophys J R Astron Soc 1976; 45: 483-94.

[42] Chorowicz J. The east African rift system. J Afr Earth Sci 2005; 43: 379-10.

[43] Axelrod DI, Raven PH. Late cretaceous and Tertiary vegetation history of Africa. In: Werger MJA, Ed. Biogeography and ecology of Southern Africa. The Hague: Dr W. Junk Publications 1978; pp.77-130.

[44] Lovett JC. Climatic history and forest distribution in eastern Africa. eastern Arc moist flora. In: Lovett JC, Wasser SK, Eds. Biogeography and ecology of the rain forests of eastern Africa. Cambridge, UK: Cambrigde University Press 1993; pp. 23-55.

[45] Coppes Y. East side story: the origin of humankind. Sci Am 1994; 270: 62-9.

[46] Beresford P. Molecular systematics and biogeography of certain Guineo-Congolian passerines. Ph.D. dissertation. USA: City University of New York 2002.

[47] Jacobs BF, Kingston JD, Jacobs LL. The origin of grass-dominated ecosystems. Ann Mo Bot Gard 1999; 86: 590-643.

[48] Flenley JR. Palynological richness and the tropical rainforest. In: Bermingham E, Dick CW, Moritz C, Eds. Tropical rainforests: past, present, and future. Chicago: Chicago University Press 2005; pp. $72-7$.

(C) Nguembock et al.; Licensee Bentham Open.

This is an open access article licensed under the terms of the Creative Commons Attribution Non-Commercial License (http://creativecommons.org/licenses/ by-nc/3.0/) which permits unrestricted, non-commercial use, distribution and reproduction in any medium, provided the work is properly cited. 